\title{
Hydrogeochemistry and Usability of Groundwater at the Tista River Basin in Northern Bangladesh
}

\author{
Md. Jahidul Islam 1, , , AKM Mosharof Hossain², Md. Shazadur Rahman', \\ Md. Hasel Khandoker ${ }^{1}$ and Mst. Nasrin Zahan ${ }^{1}$ \\ 'Department of Agricultural Chemistry, Hajee Mohammad Danesh Science and Technology University, Dinajpur, \\ Bangladesh; jahidul@hstu.ac.bd, shazadur07@hstu.ac.bd,ahmedsonali@yahoo.com, nasrinzahan01@gmail.com \\ 2Department of Soil Science, Hajee Mohammad Danesh Science and Technology University, \\ Dinajpur, Bangladesh; akmmhstu@yahoo.com
}

\begin{abstract}
Objectives: A study on groundwater of Lalmonirhat Sadar Upazila, Bangladesh has been conducted to explore the groundwater hydrochemistry and suitability for potable water and agricultural uses. Methods/statistical analysis: During the dry season, fifty groundwater samples were collected from different shallow tube wells adjacent to Tista River, Bangladesh. Water samples were analysed according to the standard procedures. We calculated some parameters required for assessing irrigation water quality. The correlation matrix, hierarchical cluster analysis (HCA), and principal component analysis (PCA) were used for better understanding of groundwater chemistry and categorizing the water samples. Findings: The $\mathrm{Ca}^{2+}-\mathrm{Mg}^{2+}-\mathrm{CO}_{3}{ }^{2-}-\mathrm{HCO}_{3}{ }^{-}$was the dominant water type, and carbonate weathering was the main hydro geochemical process in the study area. The contributions of ion exchange and reverse ion exchange were almost equal. Groundwater characteristics were influenced by precipitation and not affected by seawater intrusion. The results of all the measured and calculated parameters clearly indicated the suitability of all ground water samples for irrigation. Based on all analysed parameters including hardness, all waters were suitable for drinking and domestic uses. Applications: The groundwater of the study area might be suitable for irrigation, drinking and domestic uses until the waters are otherwise polluted.
\end{abstract}

Keywords: Hydrogeochemistry, Groundwater, Irrigation, Drinking, Bangladesh

\section{Introduction}

For sustainable development, groundwater is a ubiquitous source of water for agricultural, domestic, and drinking purposes. At present, the uses of groundwater in the Earth for irrigation and domestic purposes are $40 \%$ and $70 \%$, respectively. The declining quality of surface water resources has forced the people to become more dependent on groundwater. Consequently, the overexploitation and deterioration of groundwater has been observed worldwide. $1, \underline{2}$ In Bangladesh, groundwater is the prime source for $75 \%$ irrigation $^{3}$ and $90 \%$ drinking uses ${ }^{4}$ and these demands could be increased day by day. However, groundwater chemistry is controlled by the geological make-up, weathering of rocks, recharge water quality, and other sources.., 6 Water quality related to geology, climate, sources, and uses can be explained by the chemical analysis of water. ${ }^{\underline{7}}$ Especially, major ions in water can help explain the geochemical processes influencing groundwater quality.,$\underline{9}$

For successful crop production, water quality is an important component for irrigation. Because the ionic concentrations in irrigation water have a direct or indirect effect on plant nutrition or soil characteristics. The concentrations of different anions and captions may increase in groundwater due to chemical fertilizers, industrial, and domestic wastes. $\frac{10}{}$ The changes in groundwater quality can be easily explained by its chemistry. Some research in other regions has investigated the irrigation water quality on crop production or

${ }^{*}$ Author for correspondence 
soil properties. 11 Studies in Bangladesh $\underline{3}, \underline{4}$ showed that $\mathrm{HCO}_{3}^{-}, \mathrm{Na}^{+}, \mathrm{Ca}^{2+}, \mathrm{Mg}^{2+}$, and $\mathrm{Cl}^{-}$were the prevalent ions in groundwater collected from different regions. In Bangladesh, farmers face acute shortage of irrigation water during dry season and use groundwater sources for irrigation. Besides this, water of desirable quality is necessary for drinking and domestic purposes. Thus the water quality assessment is the most significant aspect of water management irrespective of its utility.

Lalmonirhat Sadar Upazila is a densely populated area compared to the other Upazilas of Lalmonirhat district. There is no systematic study on the groundwater quality of Lalmonirhat Sadar Upazila for irrigation and drinking purposes. The investigation on groundwater quality is an important task for safety and survival of human population. In Bangladesh, arsenic contamination of groundwater at shallow aquifer is from geogenic sources $\frac{12}{}$ and irrigation with this water increases the arsenic uptake in field crops causing ultimate deposition of arsenic in the human body. But the people are using the groundwater for both the irrigation and drinking purposes. A systematic investigation of the groundwater of this Upazila is, however, necessary for assessing the geochemistry of groundwater and its suitability for various purposes. Therefore, the objectives were to characterise the physicochemical properties of groundwater, assess the processes controlling the groundwater chemistry, and evaluate suitability for irrigation, drinking, and domestic uses.

\section{Materials and Methods}

\subsection{Geological Settings}

In Bangladesh, the aquifer systems have not been divided stratigraphically. However, the aquifers are 1) upper shallower aquifer, 2) main aquifer, and 3) deep aquifer. $\underline{13}$ We collected the waters from the main aquifer. This aquifer occurs at depths from $5 \mathrm{~m}$ to $75 \mathrm{~m}$ and is the main water bearing zone. This zone is mainly semi-confined or leaky, stratified interconnected and unconfined. Medium and coarse grained sediments inter bedded with gravel is around $140 \mathrm{~m}$ from the ground surface.

\subsection{Collection of Groundwater Samples}

The groundwater samples were collected in the month of March-April 2016 from Lalmonirhat Sadar Upazila in the district of Lalmonirhat adjacent to Tista River,
Bangladesh. Water levels are very low in these months. Fifty samples were collected from different shallow tube wells in the study area. Figure 1 shows the information of water sampling sites. Water samples were collected in 2 $\mathrm{L}$ plastic bottles. The bottles and glassware were washed with P-free detergent, and rinsed three times with ultrapure water. After soaking in $10 \%(\mathrm{v} / \mathrm{v}) \mathrm{HCl}$ for $24 \mathrm{~h}$, the bottles and glassware were again rinsed three times with ultra-pure water. All water samples were collected directly at the wellhead. Before sampling, plastic bottles were again rinsed 3-4 times with water to be sampled. The samples were analysed as quickly as possible on arrival at the laboratory.

\subsection{Measurements of Physicochemical}

\section{Parameters}

Using portable meters (Thermo, Orion), we measured electrical conductivity (EC), $\mathrm{pH}$, and temperature. After filtration $(0.45 \mu \mathrm{m})$, alkalinity was measured by titration with $0.02 \mathrm{~N} \mathrm{H}_{2} \mathrm{SO}_{4}$ until the $\mathrm{pH}$ reached at 4.3. Hydrochloric acid was used to acidify the samples to maintain the $\mathrm{pH}<2$ for analysis of cations and silica, and all the samples were stored at a temperature of $4{ }^{\circ} \mathrm{C}$. Total dissolved solids (TDS) was measured by drying and

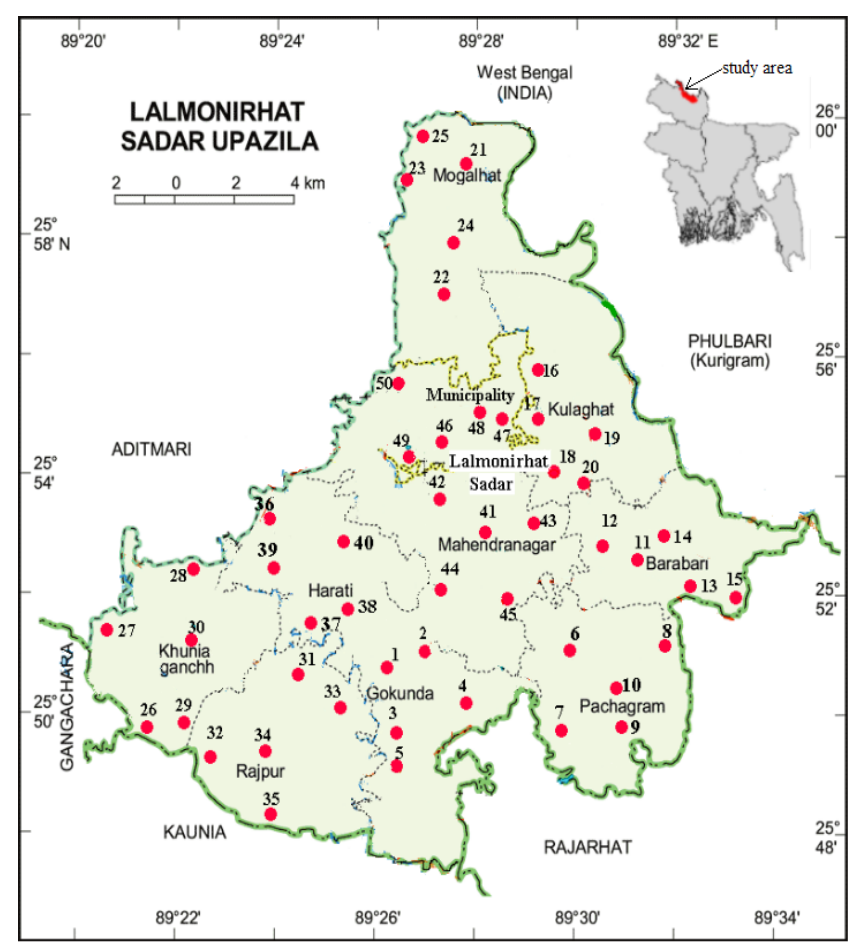

Figure 1. Map of Lalmonirhat Sadar Upazila indicating the groundwater sampling sites (red circles) along with the 
weighing method. $\mathrm{Zn}^{2+}, \mathrm{Cu}^{2+}, \mathrm{Mn}^{2+}, \mathrm{As}^{3+}$, and $\mathrm{Fe}^{3+}$ were determined by atomic absorption spectrophotometry. 14 $\mathrm{Ca}^{2+}$ and $\mathrm{Mg}^{2+}$ were measured by complexometric titration. $\mathrm{K}^{+}$and $\mathrm{Na}^{+}$were analysed by flame emission spectrophotometry. Boron $(\mathrm{B})$ and silicon dioxide $\left(\mathrm{SiO}_{2}\right)$ were analysed using spectrophotometer (DR 2800). $\mathrm{SO}_{4}{ }^{2-}$ was determined turbid metrically. $\mathrm{CO}_{3}{ }^{2-}$ and $\mathrm{HCO}_{3}{ }^{-}$ were analysed titrimetrically. $\mathrm{PO}_{4}{ }^{3-}$ and $\mathrm{NO}_{3}{ }^{-}$were determined colorimetrically. $\underline{\underline{14}}$ Chloride was estimated by argentometric titration. ${ }^{14}$ Fluoride $\left(\mathrm{F}^{-}\right)$was estimated by ion chromatography. After treating the sample with $\mathrm{KMnO}_{4}$ and $\mathrm{NaOH}$, and digestion, the chemical oxygen demand $\left(\mathrm{COD}_{\mathrm{Mn}}\right)$ was estimated titrimetrically.

\subsection{Quality Assurance and Quality Control}

For any analysis, accuracy is very important for explaining the experimental result. Standard procedures were used for measuring all parameters. The accuracies of chemical analyzes were checked by means of externally supplied standards with known standards added to samples and reagent blanks, and also calibration check standards. The precision of measurements was checked taking three replicates of the sample. All reagents used in chemical analysis were from Merck Company. The differences between the sum of cations and the sum of anions and the measured or calculated TDS to EC ratio were used for detecting discrepancies. The sum of anions and cations expressed as meq/L must be balanced because all potable waters are electrically neutral. The difference between the anion and caption sums fell between acceptable limits (5-10\%) and the percentage of difference is calculated on the basis of the following equation:

$$
\% \text { difference }=\frac{\sum \text { cations }-\sum \text { anions }}{\sum \text { cations }+\sum \text { anions }} \times 100
$$

The ratios of calculated or measured TDS to EC were from 0.55 to 0.70 which are quite acceptable for chemical analysis of water.

\subsection{Evaluation of Water Quality}

The equations related to the irrigation water class rating and hydrochemistry of groundwater were as follows:

a) Sodium adsorption ratio (SAR)

$$
\mathrm{SAR}=\frac{\mathrm{Na}+}{\sqrt{\frac{\mathrm{Ca}^{2+}+\mathrm{Mg}^{2+}}{2}}}
$$

b) Residual sodium carbonate (RSC)

$$
\mathrm{RSC}=\left(\mathrm{CO}_{3}{ }^{2-}+\mathrm{HCO}_{3}^{-}\right)-\left(\mathrm{Ca}^{2+}+\mathrm{Mg}^{2+}\right)
$$

c) Hardness or total hardness $\left(\mathrm{H}_{\mathrm{T}}\right)$

$$
\mathrm{H}_{\mathrm{T}}=2.5 \times \mathrm{Ca}^{2+}+4.1 \times \mathrm{Mg}^{2+}
$$

d) Permeability index $(\mathrm{PI})=\frac{\mathrm{Na}^{+}+\sqrt{\mathrm{HCO}_{3}^{-}}}{\mathrm{Ca}^{2+}+\mathrm{Mg}^{2+}+\mathrm{Na}^{+}}$

e) Potential salinity; $\mathrm{PS}=\mathrm{Cl}^{-}+\left(\frac{\mathrm{SO}_{4}^{2-}}{2}\right)$

f) Gibbs ratio for cation; GRFC $=\frac{\mathrm{Na}^{+}+\mathrm{K}^{+}}{\mathrm{Na}^{+}+\mathrm{K}^{+}+\mathrm{Ca}^{2+}}$

g) Gibbs ratio for anion; $\mathrm{GRFA}=\frac{\mathrm{Cl}^{-}}{\mathrm{Cl}^{-}+\mathrm{HCO}_{3}^{-}}$

h) Chloroalkaline index I (CAI-I) and chloroalkaline index II (CAI-II)

$$
\begin{gathered}
\mathrm{CAI}-\mathrm{I}=\frac{\mathrm{Cl}^{-}-\left(\mathrm{Na}^{+}+\mathrm{K}^{+}\right)}{\mathrm{Cl}^{-}} \\
\mathrm{CAI}-\mathrm{II}=\frac{\mathrm{Cl}^{-}-\left(\mathrm{Na}^{+}+\mathrm{K}^{+}\right)}{\mathrm{SO}_{4}{ }^{2-}+\mathrm{HCO}_{3}^{-}+\mathrm{CO}_{3}{ }^{2-}+\mathrm{NO}_{3}^{-}}
\end{gathered}
$$

i) Kelly's ratio; $\mathrm{KR}=\frac{\mathrm{Na}^{+}}{\mathrm{Ca}^{2+}+\mathrm{Mg}^{2+}}$

j) $\% \mathrm{Na}=\frac{\mathrm{Na}^{+}+\mathrm{K}^{+}}{\mathrm{Ca}^{2+}+\mathrm{Mg}^{2+}+\mathrm{Na}^{+}+\mathrm{K}^{+}} \times 100$

Ion concentration units are in $\mathrm{meq} / \mathrm{L}$ in all cases except hardness (mg/L).

\subsection{Multivariate Statistical Analysis}

The correlation matrix, hierarchical cluster analysis (HCA), and principal component analysis (PCA) were used for better understanding of groundwater chemistry. The Kaiser-Mayer-Olkin (KMO) measure evaluates the applicability of PCA. In this study, the KMO was 0.646. To interpret the factors of high significance, factor rotation using varimax was employed. HCA links the similar observations systematically and can easily identify different hydrochemical characteristics. For cluster analysis, Ward's method with squared Euclidean distance was applied and is the best option for dendrogram preparation. $\underline{15}$ The relations among different water parameters were detected by correlation studies. All the statistical calculations were carried out by SPSS 22 . 


\section{Results and Discussion}

\subsection{Quality Characteristics of Groundwater}

The summary results of groundwater of our study are shown in Table 1. The water temperature ranged from
22.5 to $-27.1^{\circ} \mathrm{C}$ during the study period. The $\mathrm{pH}$ of water varied from 6.4 to 8.0 and indicated that the waters were slightly acidic to slightly alkaline (Table 1 ). The COD of the study water ranged from 1.2 to $3.9 \mathrm{mgO}_{2} / \mathrm{L}$. The alkalinity and hardness values varied from 12 to $81 \mathrm{mg} / \mathrm{L}$

Table 1. Different measured and calculated parameters of the water samples collected from different sampling sites in the Lalmonirhat Sadar Upazila, Bangladesh

\begin{tabular}{|c|c|c|c|c|c|c|}
\hline Parameters & Unit & Min & Max & Mean & SD & Standard limit ${ }^{43}$ \\
\hline Depth & $\mathrm{m}$ & 13 & 80 & 29 & 15 & - \\
\hline $\mathrm{pH}$ & - & 6.4 & 8.0 & 7.25 & 0.40 & $6.5-8.0$ \\
\hline Temp & ${ }^{\circ} \mathrm{C}$ & 22.5 & 27.1 & 24.5 & 1.1 & Ambient \\
\hline $\mathrm{COD}_{\mathrm{Mn}}$ & $\mathrm{mgO}_{2} / \mathrm{L}$ & 1.2 & 3.9 & 2.5 & 0.66 & - \\
\hline $\mathrm{EC}$ & $\mu \mathrm{S} / \mathrm{cm}$ & 131 & 686 & 325 & 146 & 750 \\
\hline TDS & $\mathrm{mg} / \mathrm{L}$ & 64 & 343 & 160 & 69 & 500 \\
\hline Hardness & $\mathrm{mg} / \mathrm{L}$ & 40 & 226 & 99 & 40 & 500 \\
\hline Alkalinity & $\mathrm{mg} / \mathrm{L}$ & 12 & 81 & 31 & 14 & - \\
\hline $\mathrm{Cl}^{-}$ & $\mathrm{mg} / \mathrm{L}$ & 4 & 53 & 23 & 12 & 250 \\
\hline $\mathrm{HCO}_{3}^{-}$ & $\mathrm{mg} / \mathrm{L}$ & 49 & 207 & 101 & 37 & 200 \\
\hline $\mathrm{SO}_{4}{ }^{2-}$ & $\mathrm{mg} / \mathrm{L}$ & 0.18 & 11.72 & 1.97 & 2.03 & 200 \\
\hline $\mathrm{NO}_{3}^{-}$ & $\mathrm{mg} / \mathrm{L}$ & 1.25 & 7.21 & 4.20 & 1.45 & 50 \\
\hline $\mathrm{PO}_{4}{ }^{3-}$ & $\mathrm{mg} / \mathrm{L}$ & 0.003 & 0.019 & 0.011 & 0.004 & - \\
\hline $\mathrm{F}^{-}$ & $\mathrm{mg} / \mathrm{L}$ & 0.130 & 0.52 & 0.269 & 0.089 & $0.6-1.5$ \\
\hline $\mathrm{SiO}_{2}$ & $\mathrm{mg} / \mathrm{L}$ & 5.00 & 33.00 & 18.08 & 6.86 & - \\
\hline $\mathrm{B}$ & $\mathrm{mg} / \mathrm{L}$ & 0.028 & 0.096 & 0.061 & 0.018 & - \\
\hline $\mathrm{Ca}^{2+}$ & $\mathrm{mg} / \mathrm{L}$ & 5.61 & 37.68 & 14.69 & 6.39 & 75 \\
\hline $\mathrm{Mg}^{2+}$ & $\mathrm{mg} / \mathrm{L}$ & 5.83 & 32.08 & 15.19 & 6.16 & 30 \\
\hline $\mathrm{Na}^{+}$ & $\mathrm{mg} / \mathrm{L}$ & 5.00 & 20.00 & 9.60 & 3.40 & 200 \\
\hline $\mathrm{K}^{+}$ & $\mathrm{mg} / \mathrm{L}$ & 2.40 & 14.00 & 6.51 & 3.24 & 30 \\
\hline $\mathrm{Zn}^{2+}$ & $\mathrm{mg} / \mathrm{L}$ & 0.025 & 0.067 & 0.048 & 0.011 & - \\
\hline $\mathrm{Cu}^{2+}$ & $\mathrm{mg} / \mathrm{L}$ & 0.011 & 0.148 & 0.030 & 0.029 & 1 \\
\hline $\mathrm{Fe}^{3+}$ & $\mathrm{mg} / \mathrm{L}$ & 0.064 & 1.190 & 0.474 & 0.310 & 0.1 \\
\hline $\mathrm{Mn}^{2+}$ & $\mathrm{mg} / \mathrm{L}$ & 0.030 & 0.710 & 0.298 & 0.146 & 0.05 \\
\hline $\mathrm{As}^{3+}$ & $\mathrm{mg} / \mathrm{L}$ & 0.011 & 0.042 & 0.027 & 0.009 & 0.010 \\
\hline SAR & - & 0.21 & 0.74 & 0.36 & 0.10 & - \\
\hline$\% \mathrm{Na}$ & - & 12.53 & 37.85 & 23.47 & 6.36 & - \\
\hline RSC & meq/L & -1.41 & 0.38 & -0.35 & 0.40 & - \\
\hline PI & - & 0.48 & 1.16 & 0.74 & 0.16 & - \\
\hline PS & meq/L & 0.11 & 1.56 & 0.66 & 0.33 & - \\
\hline Kelly's ratio & - & 0.11 & 0.43 & 0.23 & 0.07 & - \\
\hline $\mathrm{Cl} / \mathrm{a}$ anions & - & 0.08 & 0.44 & 0.26 & 0.08 & - \\
\hline $\mathrm{Na} / \mathrm{Na}+\mathrm{Cl}$ & - & 0.20 & 0.71 & 0.42 & 0.11 & - \\
\hline $\mathrm{SO}_{4}{ }^{2-} / \mathrm{Cl}^{-}$ & - & 0.006 & 0.70 & 0.082 & 0.106 & - \\
\hline
\end{tabular}


and 40 to $226 \mathrm{mg} / \mathrm{L}$, respectively. We found significant variability in EC values, with the values ranging from 131 to $686 \mu \mathrm{S} / \mathrm{cm}$. The amount of TDS varied from 64 to 343 $\mathrm{mg} / \mathrm{L}$ with an average of $160 \mathrm{mg} / \mathrm{L}$ (Table 1).

The concentration of $\mathrm{K}$ was comparatively low than that of $\mathrm{Na}$ in all waters (Table 1), because $\mathrm{K}$ minerals have low ability in migration $\frac{16}{6}$ and are resistant to decomposition. $\frac{17}{}$ However, $\mathrm{Na}^{+}$ranged from 5 to $20 \mathrm{mg} / \mathrm{L}$ with a mean of $9.60 \mathrm{mg} / \mathrm{L}$. $\mathrm{Na}^{+}$usually comes from the dissolution of evaporites and silicates. ${ }^{8} \mathrm{Ca}^{2+}$ and $\mathrm{Mg}^{2+}$ are the results of carbonate dissolution in general and varied from 5.61 to 37.68 and 5.83 to $32.08 \mathrm{mg} / \mathrm{L}$, respectively. The concentrations of $\mathrm{As}^{3+}, \mathrm{Fe}^{3+}, \mathrm{Zn}^{2+}, \mathrm{Mn}^{2+}$ and $\mathrm{Cu}^{2+}$ ranged from 0.011 to $0.042 \mathrm{mg} / \mathrm{L}, 0.064$ to $1.190 \mathrm{mg} / \mathrm{L}$, 0.025 to $0.067 \mathrm{mg} / \mathrm{L}, 0.030$ to $0.710 \mathrm{mg} / \mathrm{L}$, and 0.011 to $0.148 \mathrm{mg} / \mathrm{L}$, respectively.

The concentrations of $\mathrm{CO}_{3}{ }^{2-}$ were negligible compared with $\mathrm{HCO}_{3}{ }^{-}$. The sources of $\mathrm{CO}_{3}{ }^{2-}$ and $\mathrm{HCO}_{3}{ }^{-}$are the dissolution of carbonate rocks resulting in eventual precipitation of $\mathrm{CO}_{2} \cdot{ }^{16}$ Sedimentary rocks and chloride salts are the sources of $\mathrm{Cl}^{-} .{ }^{17}$ The dominant natural sources of $\mathrm{SO}_{4}{ }^{2-}$ include rock weathering and biochemical processes. $\underline{18}$ Weathering of muscovite, biotite, fluorite, and fluoroapatite is the main cause of fluoride in groundwater. However, the concentrations of $\mathrm{HCO}_{3}^{-}, \mathrm{Cl}^{-}, \mathrm{SO}_{4}{ }^{2-}, \mathrm{NO}_{3}{ }^{-}$, $\mathrm{PO}_{4}{ }^{3-}, \mathrm{F}^{-}, \mathrm{B}$, and $\mathrm{SiO}_{2}$ ranged from 49 to $207 \mathrm{mg} / \mathrm{L}, 4$ to $53 \mathrm{mg} / \mathrm{L}, 0.18$ to $11.72 \mathrm{mg} / \mathrm{L}, 1.25$ to $7.21 \mathrm{mg} / \mathrm{L}, 0.003$ to $0.019 \mathrm{mg} / \mathrm{L}, 0.13$ to $0.52 \mathrm{mg} / \mathrm{L}, 0.028$ to $0.096 \mathrm{mg} / \mathrm{L}$, and 5 to $33 \mathrm{mg} / \mathrm{L}$, respectively. Fertilizer application can alter the major ion concentrations in groundwater in the study area.

\subsection{Mechanisms Controlling Groundwater Chemistry}

Relations among the different anions and cations are able to explain the mechanisms that control groundwater chemistry. It can be explained by the following headings.

\subsubsection{Carbonate Weathering}

In carbonate weathering, the molar ratio of $\mathrm{Ca}^{2+}+\mathrm{Mg}^{2+}$ : $\mathrm{HCO}_{3}{ }^{-}$(Figure 2Af) had greater than unity suggesting the dominancy of carbonate weathering and the source of high $\mathrm{HCO}_{3}{ }^{-}$. The possible causes are the dissolutions of gypsum, anorthite, and calcium montmorillonite and cation exchange. On the other hand, the formation of $\mathrm{CaCO}_{3}$ can decrease $\mathrm{Ca}^{2+}$ concentration with
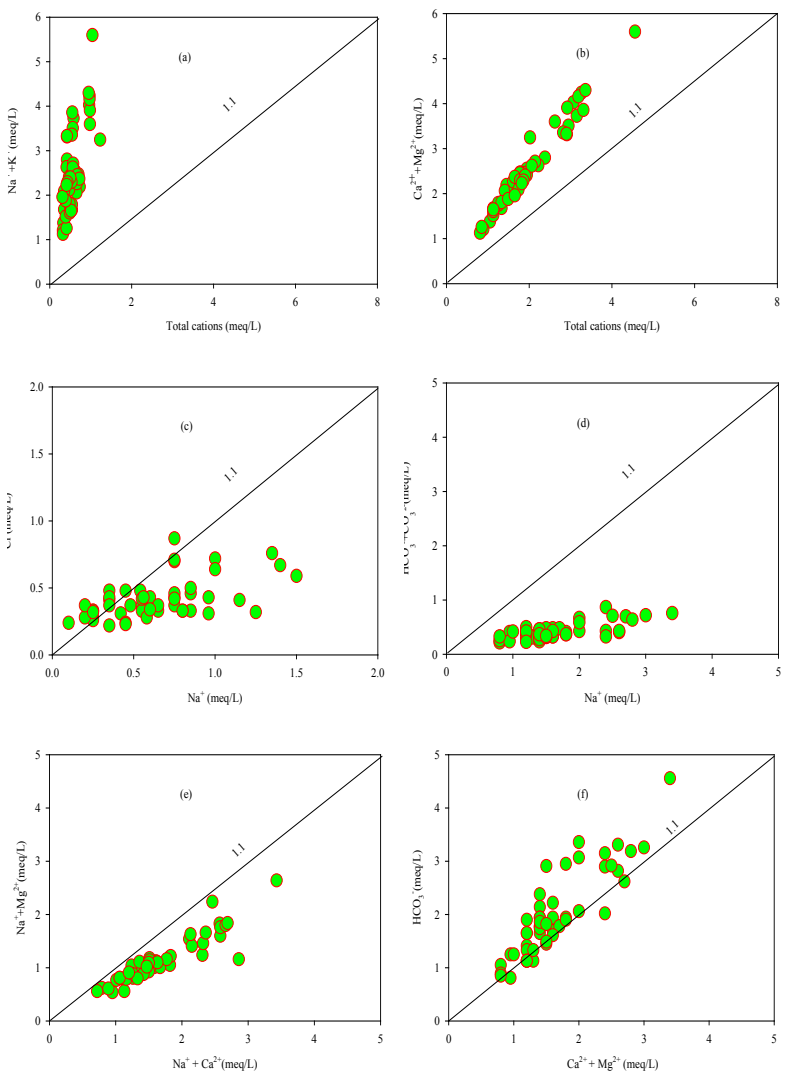

Figure 2A. Stoichiometric relations of the major cations and anions of the study water.

a proportional increase of $\mathrm{Na}^{+}$. Consequently, the $\mathrm{Mg}^{2+}: \mathrm{Ca}^{2+}$ ratio were greater than 1 (Figure 2Ae). With elevated $\mathrm{Na}^{+}$ions, $\mathrm{Mg}^{2+}$ is dominant over $\mathrm{Ca}^{2+}$ in the increased clay-rich soil. $\underline{19}$ Dominance of $\mathrm{Na}^{+}+\mathrm{Mg}^{2+}$ over $\mathrm{Na}^{+}+\mathrm{Ca}^{2+}$ in groundwater can have a greater $\mathrm{Na}^{+}$ hazard. $\underline{19}$

The $\mathrm{HCO}_{3}^{-}: \mathrm{Na}^{+}>1$ indicates carbonate weathering while its lower value suggests silicate weathering. 20 In this study, the ratios of $\mathrm{HCO}_{3}{ }^{-}+\mathrm{CO}_{3}{ }^{2-}: \mathrm{Ca}^{2+}$ (Figure 2Bi) and $\mathrm{HCO}_{3}{ }^{-}+\mathrm{CO}_{3}{ }^{2-}: \mathrm{Mg}^{2+}$ (Figure $2 \mathrm{Bj}$ ) were close to the unity reflecting the dominancy of $\mathrm{Ca}$ and $\mathrm{Mg}$-containing minerals. However, the influences of $\mathrm{Na}$-containing minerals are less because the ratio of $\mathrm{HCO}_{3}{ }^{-}+\mathrm{CO}_{3}{ }^{2-}$ : $\mathrm{Na}^{+}$(Figure 2Ad) was far below the unity. In most cases, the ratios of $\mathrm{Ca}^{2+}+\mathrm{Mg}^{2+}$ : total cations were close to unity (Figure $2 \mathrm{Ab}$ ). The ratios of $\mathrm{Na}^{+}+\mathrm{K}^{+}$: total cations indicate lower concentrations of these two cations over $\mathrm{Ca}^{2+}$ and $\mathrm{Mg}^{2+}$ (Figure 2Aa). The $\mathrm{Ca}^{2+}+\mathrm{Mg}^{2+}$ vs $\mathrm{HCO}_{3}{ }^{-}+\mathrm{SO}_{4}{ }^{2-}$ relations of most samples were approaching unity (Figure $2 \mathrm{Bg}$ ) reflecting dominancy of carbonate weathering. $\underline{\underline{21}}$ 

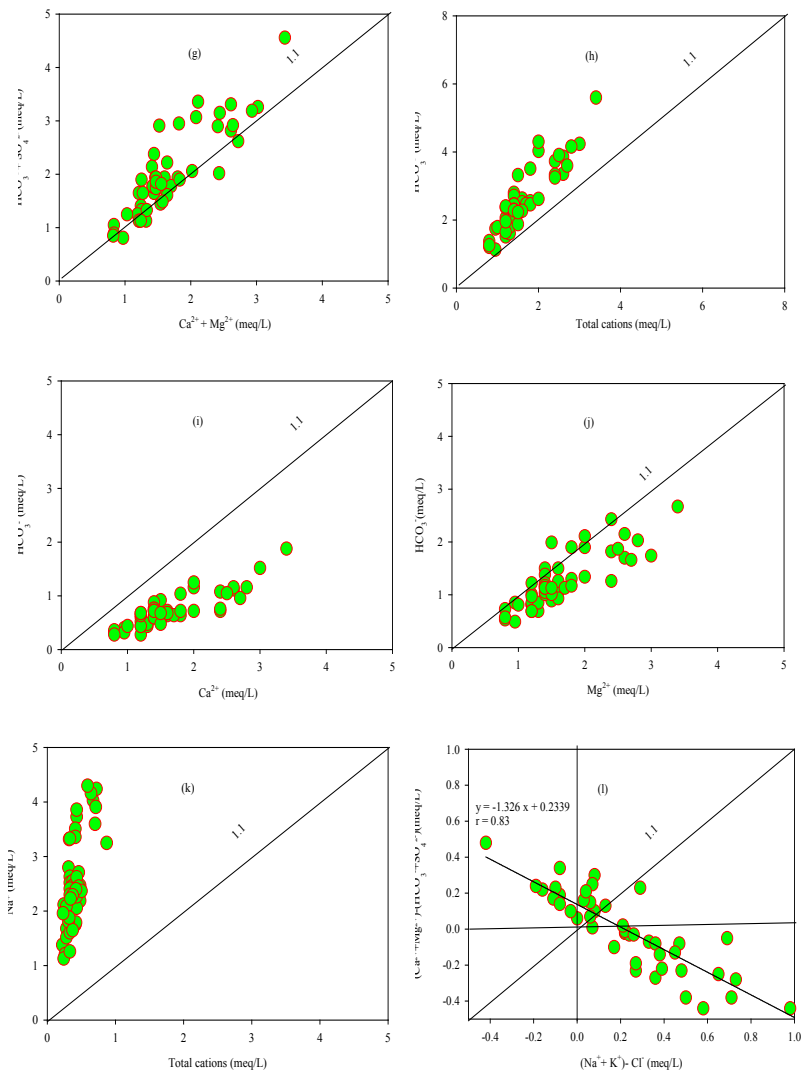

Figure 2B. Stoichiometric relations of the major cations and anions of the study water.

\subsubsection{Silicate Weathering}

The ratio of $\mathrm{Na}^{+}$: total cations (TC) indicates the levels of silicate weathering process. $\stackrel{22}{ }$ Groundwater samples had $\mathrm{Na}^{+}: \mathrm{TC}<0.25$ (Figure 2Bk) indicating that there was less silicate weathering. The ratio of $\mathrm{Na}^{+}+\mathrm{K}^{+}$: TC was 0.25 (Figure 2Aa). This implies that silicate weathering is less responsible to the supply of cations in groundwater. When carbonate and silicate minerals are the major contributors for groundwater chemistry, the $\mathrm{HCO}_{3}^{-}$: TC value would be one. $\underline{23}$ This study did not correspond well to the abovementioned mechanism (Figure 2Bh). The plotting of $\mathrm{Ca}^{2+}+\mathrm{Mg}^{2+}$ versus $\mathrm{HCO}_{3}^{-}$(Figure 2Af) further infers that the groundwater did not have an excess of $\mathrm{HCO}_{3}{ }^{-}$. This $\mathrm{HCO}_{3}{ }^{-}$was not balanced by $\mathrm{Na}^{+}$(Figure $2 \mathrm{Ad}$ ), as the silicate weathering was not a prime mechanism to release the $\mathrm{Na}^{+}$and $\mathrm{HCO}_{3}{ }^{-}$into the groundwater. The ratio of $\mathrm{Na}^{+}: \mathrm{Cl}^{-}$in most samples was lower than unity (Figure 2Ac). The dissolution of $\mathrm{NaCl}$ generates a 1:1 ratio of $\mathrm{Na}^{+}: \mathrm{Cl}^{-}$while the release of $\mathrm{Na}^{+}$from silicate weathering produces a wide ratio. $\underline{\underline{24}}$

\subsubsection{Saline Water Intrusion}

Salinity and saline water intrusions are related to $\mathrm{Na}-\mathrm{Cl}$ relationship. .55 The equations of $\mathrm{Cl}^{-} / \Sigma$ anions $>0.8$ and $\mathrm{Na}^{+} /\left(\mathrm{Na}^{+}+\mathrm{Cl}^{-}\right)<0.5$ suggest seawater intrusion into groundwater. $\stackrel{26}{ }$ In this study, the average value of $\mathrm{Cl}^{-} / \Sigma$ anions ratio was 0.26 and also $\mathrm{Na}^{+} /\left(\mathrm{Na}^{+}+\mathrm{Cl}^{-}\right)$ratio was 0.42 (Table 1). A significant correlation $(r=0.56)$ exists between $\mathrm{Na}^{+}$and $\mathrm{Cl}^{-}$suggesting that they might be originating from the same sources (Table 3). The cation exchange process may also increase $\mathrm{Na}^{+}$concentration in addition to the dissolution of halite. $\underline{27}$ Figure $2 \mathrm{Ac}$ shows the deviations of the expected $\mathrm{Na}^{+}: \mathrm{Cl}^{-}(1: 1)$ relation indicating that a fraction of $\mathrm{Na}$ is associated with another anion. In the study area, the ratio of $\mathrm{Na}^{+} / \mathrm{Cl}^{-}<1$ meaning another source is contributing chloride to the groundwater.

\subsubsection{Ion Exchange}

In aquifer, the clay minerals in unconsolidated deposits adsorb cations in their pore spaces. Ion exchange with clay materials is responsible for ionic concentration in groundwater. $\underline{28}$ In this study, the majority of the samples showed an excess of $\mathrm{Mg}^{2+}$ over $\mathrm{Ca}^{2+}$ (Figure 2Ae), which could be the dissolution of $\mathrm{Mg}$-containing minerals in addition to dolomite. The exchange of $\mathrm{Na}^{+}$in water by $\mathrm{Ca}^{2+}$ or $\mathrm{Mg}^{2+}$ in clay material can cause an excess of $\mathrm{Ca}^{2+}$ or $\mathrm{Mg}^{2+}$ in groundwater and vice versa. ${ }^{29} \mathrm{An}$ excess of $\mathrm{HCO}_{3}{ }^{-}+\mathrm{SO}_{4}{ }^{2-}$ over $\mathrm{Ca}^{2+}+\mathrm{Mg}^{2+}$ indicates ion exchange process, while an excess of $\mathrm{Ca}^{2+}+\mathrm{Mg}^{2+}$ over $\mathrm{HCO}_{3}{ }^{-}+\mathrm{SO}_{4}{ }^{2-}$ supports reverse ion exchange. $\frac{30}{} \mathrm{In}$ this study, the ratio of $\left(\mathrm{Ca}^{2+}+\mathrm{Mg}^{2+}\right) /\left(\mathrm{HCO}_{3}{ }^{-}+\mathrm{SO}_{4}{ }^{2-}\right)>1$ indicates the reverse ion exchange process (Figure $2 \mathrm{Bg}$ ). If the dissolutions of calcite, dolomite, and gypsum are dominant in water, the relationship between $\mathrm{Ca}^{2+}+\mathrm{Mg}^{2+}$ and $\mathrm{SO}_{4}{ }^{2-}+\mathrm{HCO}_{3}{ }^{-}$would be close to $1: 1$. 28 The role of ion exchange in groundwater can be evaluated by plotting $\left(\mathrm{Ca}^{2+}+\mathrm{Mg}^{2+}\right)-\left(\mathrm{HCO}_{3}^{-}+\mathrm{SO}_{4}{ }^{2-}\right)$ against $\left(\mathrm{Na}^{+}+\mathrm{K}^{+}\right)$ $-\mathrm{Cl}^{-}$. The $\left(\mathrm{Ca}^{2+}+\mathrm{Mg}^{2+}\right)-\left(\mathrm{HCO}_{3}{ }^{-}+\mathrm{SO}_{4}{ }^{2-}\right)$ relation implies that excess $\mathrm{Ca}$ and $\mathrm{Mg}$ were originated by the influences of other processes, whereas the $\left(\mathrm{Na}^{+}+\mathrm{K}^{+}\right)-$ $\mathrm{Cl}^{-}$indicates that $\mathrm{K}$ and $\mathrm{Na}$ were from the sources other than their respective chlorides. In case of the dominancy of ion exchange process, the graphical representations of the samples will form a line with a slope of $-1 . \underline{31}$ Figure $2 \mathrm{Bl}$ shows that samples had a slope of -1.326 , indicating cation exchange influences the groundwater chemistry in the study area. 
Table 2. Correlation matrix of the water quality parameters with depth

\begin{tabular}{|c|c|c|c|c|c|c|c|c|c|c|c|c|c|}
\hline & Depth & EC & TDS & $\mathrm{Cl}^{-}$ & $\mathrm{HCO}_{3}{ }^{-}$ & $\mathrm{NO}_{3}{ }^{-}$ & $\mathrm{SO}_{4}^{2-}$ & $\mathbf{F}^{-}$ & $\mathrm{Ca}^{2+}$ & $\mathrm{Mg}^{2+}$ & $\mathrm{Na}^{+}$ & $\mathbf{K}^{+}$ & SAR \\
\hline Depth & 1.00 & & & & & & & & & & & & \\
\hline $\mathrm{EC}$ & -0.04 & 1.00 & & & & & & & & & & & \\
\hline TDS & -0.03 & 0.94 & 1.00 & & & & & & & & & & \\
\hline $\mathrm{Cl}^{-}$ & 0.02 & 0.74 & 0.66 & 1.00 & & & & & & & & & \\
\hline $\mathrm{HCO}_{3}{ }^{-}$ & -0.03 & 0.88 & 0.90 & 0.55 & 1.00 & & & & & & & & \\
\hline $\mathrm{NO}_{3}^{-}$ & -0.18 & -0.27 & -0.22 & -0.21 & -0.18 & 1.00 & & & & & & & \\
\hline $\mathrm{SO}_{4}^{2-}$ & 0.06 & 0.19 & 0.16 & 0.14 & 0.00 & -0.03 & 1.00 & & & & & & \\
\hline $\mathrm{F}^{-}$ & -0.20 & 0.05 & 0.06 & -0.06 & 0.17 & 0.05 & -0.04 & 1.00 & & & & & \\
\hline $\mathrm{Ca}^{2+}$ & -0.05 & 0.87 & 0.84 & 0.78 & 0.87 & -0.28 & 0.07 & 0.13 & 1.00 & & & & \\
\hline $\mathrm{Mg}^{2+}$ & 0.10 & 0.81 & 0.79 & 0.81 & 0.84 & -0.11 & 0.10 & 0.09 & 0.88 & 1.00 & & & \\
\hline $\mathrm{Na}^{+}$ & -0.09 & 0.86 & 0.81 & 0.56 & 0.73 & -0.26 & 0.18 & -0.01 & 0.66 & 0.54 & 1.00 & & \\
\hline $\mathrm{K}^{+}$ & -0.33 & 0.69 & 0.66 & 0.48 & 0.54 & -0.14 & 0.07 & 0.07 & 0.47 & 0.36 & 0.76 & 1.00 & \\
\hline SAR & -0.15 & 0.41 & 0.38 & 0.09 & 0.25 & -0.14 & 0.14 & -0.14 & 0.09 & -0.02 & 0.80 & 0.62 & 1.00 \\
\hline
\end{tabular}

Values are significant at $p=0.05$ where $r \geq 0.28$.

\subsubsection{Chloroalkaline Index}

Two chloroalkaline indices (CAI-I and CAI-II) suggested by Schoeller $\frac{32}{2}$ were used to identify the specific ion exchange between the groundwater and its surroundings. $\frac{33}{3}$ In general, $\mathrm{Na}^{+}$and $\mathrm{K}^{+}$in groundwater are exchanged with $\mathrm{Ca}^{2+}$ and $\mathrm{Mg}^{2+}$ in aquifer matrix. An exchange between $\mathrm{Na}^{+}$or $\mathrm{K}^{+}$in water with $\mathrm{Mg}^{2+}$ or $\mathrm{Ca}^{2+}$ in rock indicates a direct ion exchange. $\mathrm{Na}^{+}$or $\mathrm{K}^{+}$will decrease in water and both the above indices will be positive. Conversely, the reverse ion exchange will produce negative indices. $\frac{33}{3}$ The negative and positive values for both indices suggest the contribution of direct ion exchange and reverse ion exchange in the system (Figure 3). Results show that $68 \%$

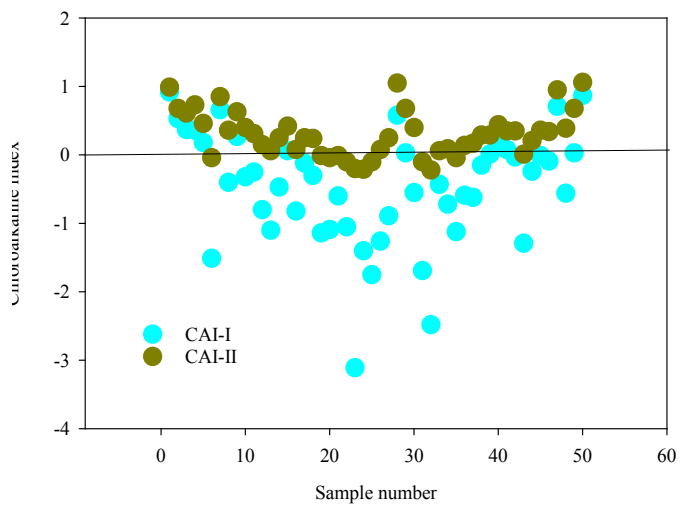

Figure 3. Variation of index of Base Exchange (CAI-I and CAI-II) against sample site numbers of the groundwater in the study area. is negative and $32 \%$ is positive in CAI-I while in CAI-II, $22 \%$ is negative and $78 \%$ is positive. On an average, the contribution of direct ion exchange and reverse ion exchange reaction is almost equal.

\subsubsection{Gibbs Ratio}

Gibbs $\underline{34}$ proposed two diagrams known as Gibbs diagrams that explain the major mechanisms governing water chemistry. These diagrams are widely used in groundwater studies $s, \underline{83}$ in addition to surface water. In our study, the water samples fell in the precipitation dominance area of Gibbs diagram (Figure 4). Due to high evapotranspiration and restricted fresh water exchange in the study area, salt layers may form in the evaporating surface. $\frac{35}{}$ On the other hand, human activities can also change the groundwater chemical composition.

\subsubsection{Piper Diagram}

Piper diagram ${ }^{36}$ can easily classify and compare the water types. The concentrations of majoranions and cations build this diagram. Groundwater samples are classified as $\mathrm{Ca}^{2+}-\mathrm{Mg}^{2+}-\mathrm{CO}_{3}{ }^{2-}-\mathrm{HCO}_{3}{ }^{-}$type (Figure 5). This signifies that the dissolution of carbonates is a predominant process releasing substantial amount of $\mathrm{Ca}^{2+}$ and $\mathrm{Mg}^{2+}$ into the groundwater of the study area. Piper's diagram confirms that all the groundwater's are characterised as alkaline earth's $\left(\mathrm{Ca}^{2+}+\mathrm{Mg}^{2+}\right)$ exceeds alkalies $\left(\mathrm{Na}^{+}+\mathrm{K}^{+}\right)$ and are described as weak acids $\left(\mathrm{CO}_{3}{ }^{2-}+\mathrm{HCO}_{3}{ }^{-}\right)$exceed strong acids $\left(\mathrm{SO}_{4}{ }^{2-}+\mathrm{Cl}^{-}+\mathrm{F}^{-}\right)$. 

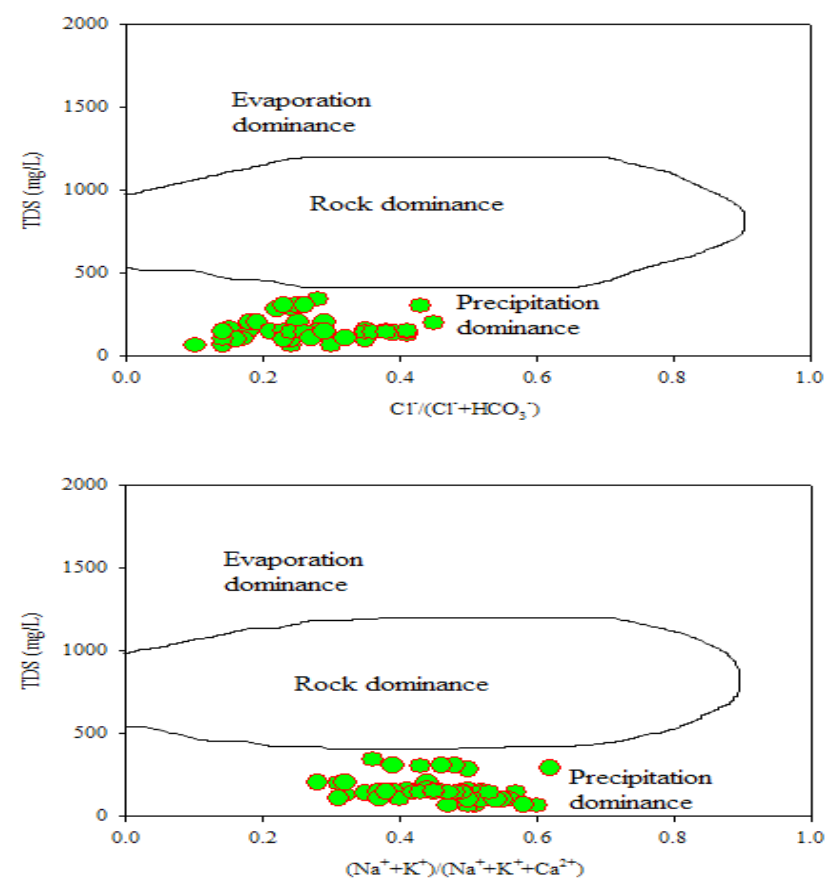

Figure 4. Gibbs diagram of groundwater in the study are

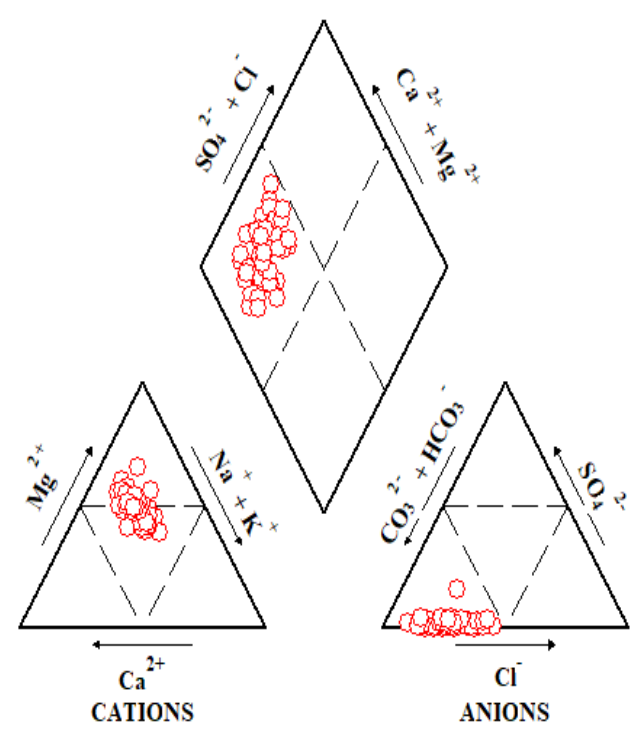

Figure 5. Piper diagram of the groundwater samples in the study area showing $\mathrm{Ca}^{2+}-\mathrm{Mg}^{2+}-\mathrm{CO}_{3}{ }^{2-}-\mathrm{HCO}_{3}{ }^{-}$type.

\subsection{Multivariate Statistical Analysis}

In this study, a Pearson correlation matrix was used to determine the relationships between variables (Table 2). There were few significant relationships among the measured concentrations with depth. The high correlations between $\mathrm{Cl}^{-}$and $\mathrm{HCO}_{3}{ }^{-}(r=0.55), \mathrm{Cl}^{-}$and $\mathrm{Na}^{+}(r=0.56), \mathrm{K}^{+}$and $\mathrm{HCO}_{3}^{-}(r=0.54), \mathrm{Na}^{+}$and $\mathrm{K}^{+}(r$ $=0.76)$, and $\mathrm{Na}^{+}$and $\mathrm{HCO}_{3}{ }^{-}(r=0.73)$ indicate that they most likely derive from the same sources of water (Table 2). The relation between $\mathrm{Ca}^{2+}-\mathrm{HCO}_{3}{ }^{-}(r=0.87)$ and $\mathrm{Ca}^{2+}-\mathrm{Na}^{+}(r=0.66)$ might represent the contributions of carbonate and silicate weathering.

PCA was applied to the 24 physicochemical parameters, but only eight PCs with eigenvalue greater than 1 are considered to be the most important (Table 3 ). The high eigenvalue indicates the greater contribution to the variability of the groundwater chemistry. The PC loadings were categorised into strong, moderate, and weak corresponding to the absolute loading values of $>0.75,0.75-0.50$, and $0.50-0.30$, respectively. ${ }^{37} \mathrm{~A}$ total of eight factors were accredited responsible for groundwater chemistry in the study area accounting $76.80 \%$ of the total variance (Table 3). Factor-1 has the highest loading (33.33\%) and the contributors include $\mathrm{Ca}^{2+}, \mathrm{HCO}_{3}{ }^{-}, \mathrm{Cl}^{-}$, $\mathrm{Mg}^{2+}, \mathrm{Na}^{+}, \mathrm{K}, \mathrm{EC}, \mathrm{TDS}$, hardness, and alkalinity. These major ions might be due to bedrock dissolution arising from rock-water interaction.

Examination of Figure 6 led to the identification of three major clusters in the dendrogram labeled as cluster 1 , cluster 2, and cluster 3 . The majority of samples (28) were grouped in cluster 1 . Their similarity could support the hypothesis of a common evolutional trend to the study area. The cluster 2 and cluster 3 include 12 samples and 10 samples, respectively. The linkage distance is highest in cluster 3 followed by cluster 1 and cluster 2 .

\subsection{Irrigation Suitability}

For agricultural use, the suitable $\mathrm{pH}$ ranges from 6.0 to $8.5 \underline{38}$ and all waters were suitable. The permeability index (PI) ranging from 48 to $116 \%$ locates under Class I and Class II (Table 1). These two classes allow $75 \%$ or more permeability of irrigation waters. Groundwater with Kelly's ratio greater than one is not good for irrigation. In this study, Kelly's ratio ranged from 0.11 to 0.43 indicating the suitability of all the samples for irrigation (Table 1).

High EC values may relate to salinity hazard. Table 4 shows that out of 50 samples, $30 \%$ were as 'excellent' and $70 \%$ were rated as 'good' for irrigation. $\frac{39}{}$ According to Richards 10 waters were C1S1 (30\%) and C2S1 (70\%) categories. C1 indicates 'low' salinity $(\mathrm{EC}<250 \mu \mathrm{S} / \mathrm{cm})$, 
Table 3. Varimax rotated factor loading of groundwater chemistry in Lalmonirhat

\begin{tabular}{|c|c|c|c|c|c|c|c|c|}
\hline Variables & Factor 1 & Factor 2 & Factor 3 & Factor 4 & Factor 5 & Factor 6 & Factor 7 & Factor 8 \\
\hline $\mathrm{pH}$ & -0.240 & 0.072 & 0.087 & 0.146 & -0.742 & 0.132 & 0.078 & 0.166 \\
\hline Temp & 0.090 & -0.467 & 0.451 & 0.061 & 0.484 & 0.079 & -0.099 & -0.015 \\
\hline $\mathrm{COD}$ & 0.144 & 0.033 & -0.085 & -0.088 & -0.151 & 0.117 & 0.859 & 0.005 \\
\hline EC & 0.955 & 0.063 & 0.062 & -0.143 & 0.007 & -0.059 & -0.114 & -0.002 \\
\hline TDS & 0.938 & 0.019 & 0.047 & -0.117 & 0.058 & -0.003 & -0.039 & 0.058 \\
\hline Hard & 0.950 & 0.047 & -0.022 & 0.192 & 0.013 & -0.010 & 0.098 & -0.033 \\
\hline Alka & 0.893 & 0.007 & 0.049 & 0.139 & 0.026 & 0.018 & 0.075 & 0.064 \\
\hline $\mathrm{Cl}$ & 0.820 & -0.134 & 0.046 & 0.142 & 0.017 & 0.037 & 0.028 & -0.270 \\
\hline $\mathrm{HCO}_{3}$ & 0.905 & 0.176 & -0.039 & -0.047 & 0.020 & -0.066 & 0.022 & 0.141 \\
\hline $\mathrm{SO}_{4}$ & 0.109 & 0.002 & 0.816 & -0.121 & -0.124 & 0.228 & 0.015 & -0.148 \\
\hline $\mathrm{NO}_{3}$ & -0.266 & 0.107 & 0.135 & 0.085 & 0.370 & -0.228 & 0.541 & 0.003 \\
\hline $\mathrm{PO}_{4}$ & -0.047 & 0.147 & 0.188 & -0.155 & -0.131 & 0.816 & 0.054 & -0.131 \\
\hline $\mathrm{F}$ & 0.053 & 0.715 & -0.028 & -0.003 & 0.024 & 0.040 & 0.230 & 0.119 \\
\hline $\mathrm{SiO}_{2}$ & -0.052 & 0.211 & 0.650 & 0.147 & -0.041 & -0.394 & -0.036 & 0.301 \\
\hline$B$ & -0.085 & 0.196 & -0.334 & 0.077 & 0.561 & 0.088 & 0.070 & 0.358 \\
\hline $\mathrm{Ca}$ & 0.938 & 0.091 & -0.014 & 0.146 & 0.018 & -0.010 & -0.080 & -0.052 \\
\hline $\mathrm{Mg}$ & 0.912 & 0.017 & -0.026 & 0.211 & 0.009 & -0.010 & 0.205 & -0.020 \\
\hline $\mathrm{Na}$ & 0.792 & 0.026 & 0.092 & -0.361 & 0.031 & -0.060 & -0.230 & 0.028 \\
\hline $\mathrm{K}$ & 0.624 & 0.199 & 0.089 & -0.425 & 0.081 & -0.005 & -0.123 & -0.032 \\
\hline $\mathrm{Zn}$ & -0.233 & -0.834 & -0.135 & -0.050 & 0.010 & -0.095 & 0.215 & 0.132 \\
\hline $\mathrm{Cu}$ & -0.065 & -0.342 & -0.174 & -0.568 & -0.293 & 0.002 & -0.113 & 0.037 \\
\hline $\mathrm{Fe}$ & 0.166 & -0.078 & -0.105 & 0.728 & -0.220 & -0.043 & -0.166 & -0.161 \\
\hline $\mathrm{Mn}$ & -0.060 & 0.014 & -0.009 & 0.153 & 0.047 & 0.018 & -0.008 & -0.860 \\
\hline As & -0.119 & -0.011 & -0.179 & 0.333 & 0.086 & 0.605 & -0050 & 0.357 \\
\hline Eigen values & 8.000 & 1.775 & 1.593 & 1.584 & 1.451 & 1.363 & 1.346 & 1.319 \\
\hline$\%$ of variance & 33.335 & 7.397 & 6.638 & 6.602 & 6.047 & 5.678 & 5.607 & 5.496 \\
\hline Cumulative \% & 33.335 & 40.733 & 47.370 & 53.972 & 60.019 & 65.697 & 71.304 & 76.801 \\
\hline
\end{tabular}

Bold values indicate absolute values $>0.5$ of parameters with strong loading value

$\mathrm{C} 2$ indicates 'medium' salinity $(\mathrm{EC}=250-750 \mu \mathrm{S} / \mathrm{cm})$, and S1 indicates 'low sodium'. In this study, $30 \%$ samples were rated as 'excellent' and $70 \%$ samples were rated as 'good' according to \% Na. $\frac{39}{}$ As for RSC values, all water samples were graded as 'suitable. Based on hardness, $30 \%$ samples were classified as 'soft', $56 \%$ samples were grouped as 'moderately hard', and $14 \%$ samples were as 'hard' (Table 4).

All the waters were rated as 'fresh' (TDS $<1000 \mathrm{mg} / \mathrm{L}$ ) suggested by Freeze and Cherry. ${ }^{41}$ Based on major cations, all the study waters were below the permissible limits $\left(\mathrm{Ca}^{2+}=80 \mathrm{mg} / \mathrm{L}, \mathrm{Mg}^{2+}=35 \mathrm{mg} / \mathrm{L}, \mathrm{Na}^{+}=200 \mathrm{mg} / \mathrm{L}\right.$, $\left.\mathrm{K}^{+}=30 \mathrm{mg} / \mathrm{L}\right)$. $\underline{42}$ The chloride concentration should be below $140 \mathrm{mg} / \mathrm{L}$ in irrigation water, $\underline{38}$ and all waters were suitable for irrigation. The groundwater $\mathrm{NO}_{3}{ }^{-}-\mathrm{N}$ did not exceed the maximum concentration $(30 \mathrm{mg} / \mathrm{L})$ as because most crops are relatively unaffected below this value. $\underline{38}$ The lower concentrations of $\mathrm{Cu}^{2+}, \mathrm{Zn}^{2+}, \mathrm{Fe}^{3+}, \mathrm{As}^{3+}$, and $\mathrm{Mn}^{2+}$ might be suitable for crop production and soil environment.

\subsection{Drinking and Public Health Suitability}

In this study, the $\mathrm{pH}(6.4-8.0)$ of all groundwater samples was safe (safe limit 6.5-8.5) for drinking water prescribed by WHO. .33 The recommended concentration of TDS is 500 $\mathrm{mg} / \mathrm{L}, \underline{43}$ and all waters were suitable for drinking. The $\mathrm{Na}^{+}$ concentration should be below $200 \mathrm{mg} / \mathrm{L}$. $\underline{43}$ People can feel 


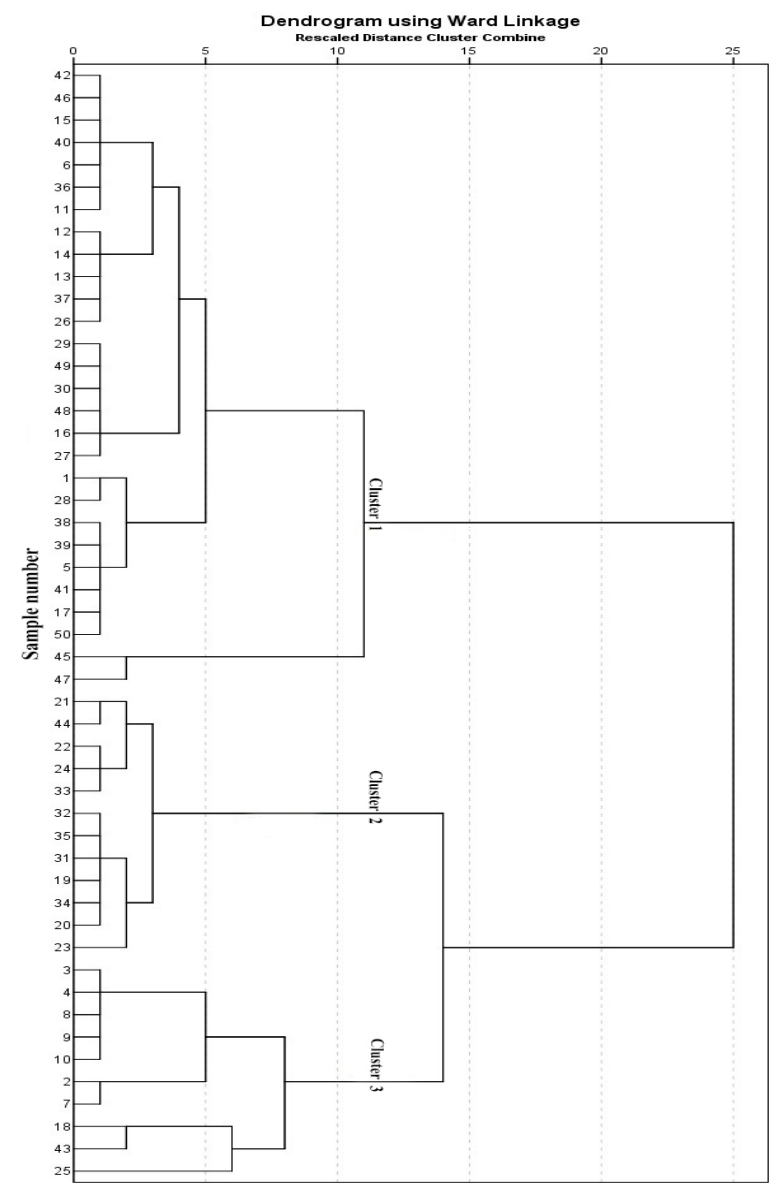

Figure 6. HCA analysis of the groundwater of the study sites.

a salty taste if there is an excess of $\mathrm{Cl}^{-}$present in drinking water. Hypertension, methemoglobinemia, and gastric cancer are the consequences of high $\mathrm{NO}_{3}{ }^{-}$concentration in drinking water. However, the concentrations of $\mathrm{Cl}^{-}$, $\mathrm{SO}_{4}{ }^{2-}$, and $\mathrm{NO}_{3}{ }^{-}$of the studied groundwater samples were under the permissible limits. $\mathrm{WHO}^{43}$ suggests the maximum permissible limit of $\mathrm{Cl}^{-}, \mathrm{SO}_{4}{ }^{2-}$, and $\mathrm{NO}_{3}{ }^{-}$in drinking water should be $250 \mathrm{mg} / \mathrm{L}, 150 \mathrm{mg} / \mathrm{L}$, and 10 $\mathrm{mg} / \mathrm{L}$, respectively. The content of As is above the WHO guideline for drinking water $(<0.01 \mathrm{mg} / \mathrm{L}) \stackrel{43}{3}$ but below the Bangladesh limit $(<0.05 \mathrm{mg} / \mathrm{L})$. Concentration of $\mathrm{Fe}$ of almost all the samples exceeded the WHO permissible limit $(<0.1 \mathrm{mg} / \mathrm{L})$. The mean value of $\mathrm{Mn}(0.298 \mathrm{mg} / \mathrm{L})$ was above the WHO guideline for drinking water $(<0.05$ $\mathrm{mg} / \mathrm{L}$ ). Exposure to high levels of manganese can cause a disease manganism characterised by a Parkinson-like syndrome showing weakness, muscle pain, apathy, and slow clumsy movement of limbs. Hard water may cause high incidence of urolithiosis, $\underline{43}$ anencephaly, parental
Table 4. Water quality rating for irrigation in the study area

\begin{tabular}{|c|c|c|c|}
\hline Parameters & Reference & Range & Category (\%) \\
\hline \multirow[b]{2}{*}{$\mathrm{EC}$} & \multirow[b]{2}{*}{39} & $<250 \mu \mathrm{S} / \mathrm{cm}$ & Excellent (30\%) \\
\hline & & $250-750 \mu \mathrm{S} / \mathrm{cm}$ & Good (70\%) \\
\hline SAR & 40 & $<10$ & $\begin{array}{l}\text { Excellent } \\
(100 \%)\end{array}$ \\
\hline TDS & 41 & $0-1000 \mathrm{mg} / \mathrm{L}$ & $\begin{array}{l}\text { Freshwater } \\
(100 \%)\end{array}$ \\
\hline \multirow[b]{3}{*}{ Hardness } & \multirow[b]{3}{*}{44} & $<75 \mathrm{mg} / \mathrm{L}$ & Soft $(30 \%)$ \\
\hline & & $75-150 \mathrm{mg} / \mathrm{L}$ & $\begin{array}{l}\text { Moderately } \\
\text { hard }(56 \%)\end{array}$ \\
\hline & & $150-300 \mathrm{mg} / \mathrm{L}$ & Hard (14\%) \\
\hline RSC & 45 & $<1.25 \mathrm{meq} / \mathrm{L}$ & Suitable $(100 \%)$ \\
\hline $\begin{array}{l}\text { Kelly's } \\
\text { ratio }\end{array}$ & 46 & $<1$ & Suitable (100) \\
\hline \multirow{2}{*}{$\begin{array}{l}\text { Percentage } \\
\text { of } \mathrm{Na}\end{array}$} & \multirow[b]{2}{*}{39} & $<20$ & Excellent $(30 \%)$ \\
\hline & & $20-40$ & Good (70\%) \\
\hline \multirow{2}{*}{$\begin{array}{l}\text { Alkalinity- } \\
\text { salinity } \\
\text { class }\end{array}$} & \multirow[b]{2}{*}{40} & $\begin{array}{l}\mathrm{C} 1<250 \mu \mathrm{S} / \\
\mathrm{cm}, \mathrm{S} 1<10\end{array}$ & C1S1 (30\%) \\
\hline & & $\begin{array}{l}\mathrm{C} 2=250-750 \\
\mu \mathrm{S} / \mathrm{cm}\end{array}$ & C2S1 (70\%) \\
\hline
\end{tabular}

mortality, and cardio-vascular disorders. This water also develops scales in distribution pipes and cooking utensils, and requires more soap for washing clothes. $\underline{35}$

\section{Conclusion}

Groundwater quality of Lalmonirhat Sadar Upazila was measured for drinking and agricultural purposes. The findings of this study are as follows:

- The major cations in the study area were in the order of $\mathrm{Mg}^{2+}>\mathrm{Ca}^{2+}>\mathrm{Na}^{+}>\mathrm{K}^{+}$. The anions were also arranged in decreasing order as $\mathrm{HCO}_{3}^{-}>\mathrm{Cl}^{-}>\mathrm{NO}_{3}{ }^{-}$ $>\mathrm{SO}_{4}^{2-}$.

- The dominant water type was $\mathrm{Ca}^{2+}-\mathrm{Mg}^{2+}-\mathrm{CO}_{3}{ }^{2-}$ $\mathrm{HCO}_{3}{ }^{-}$and the study area is a precipitation dominance area.

- Based on Wilcox requirement and SAR, the groundwater might be suitable for irrigation without salinity hazard.

- Carbonate weathering was the main component for controlling groundwater chemistry followed by silicate weathering and ion exchange processes. 
- The PCA and HCA explain the variations of different anions and cations and also the anthropogenic causes. Anthropogenic activities might cause the excess concentrations of some anions and cations.

- Accumulated salts on soil surfaces generated by irrigation can leach by recharge water and reach the water table, and could become a cause of groundwater pollution. And recycling of groundwater for irrigation can increase soil and groundwater salinity.

- According to the measured parameters such as $\mathrm{pH}$, TDS, $\mathrm{Na}^{+}, \mathrm{Cl}^{-}, \mathrm{SO}_{4}{ }^{2-}, \mathrm{NO}_{3}{ }^{-}$, and semi-heavy metals $(\mathrm{Cu}, \mathrm{Zn}, \mathrm{Fe}, \mathrm{Mn}$, and $\mathrm{As})$, all waters were suitable for drinking and domestic purposes.

Based on observed patterns, it can be concluded that all the groundwater samples of the Upazila, Bangladesh were suitable for irrigation, drinking, and domestic uses. However, continuous monitoring of groundwater in the study area would be useful for predicting the suitability for irrigation and drinking purposes in the upcoming days.

\section{Acknowledgements}

We gratefully thank for the financial supports from the Institute of Research and Training (IRT), Hajee Mohammad Danesh Science and Technology University, Dinajpur-5200, Bangladesh (HSTU/IRT/1562 and HSTU/ IRT/1822). The authors also acknowledge the Chairman of the Department of Agricultural Chemistry, Hajee Mohammad Danesh Science and Technology University, Dinajpur-5200, Bangladesh for conducting this research in the laboratory of the Agricultural Chemistry.

\section{References}

1. Taylor RG, Scanlon B, Döll P, Rodell M, Beek RV, Wada Y, et al. Ground water and climate change. Nature Clim Change. 2013:3(4):322-9.

2. MacDonald AM, Bonsor HC, Ahmed KM, Burgess WG, Basharat M, Calow RC, et al. Groundwater quality and depletion in the indo-gangetic basin mapped from in situ observations. Nature Geosci. 2016;9:762-6.

3. Shahid S, Chen X, Hazarika MK. Evaluation of groundwater quality for irrigation in Bangladesh using geographic information system. J Hydrol Hydromech. 2006;54(1):3-14.

4. Mridha MAK, Rashid MH, Talukder KH. Quality of groundwater for irrigation in Natore district, Bangladesh. J Agric Res. 1996;2(1):15-30.
5. Han D, Liang X, Jin M, Currell MJ, Han Y, Song X. Hydrogeochemical indicators of groundwater flow systems in the Yangwu River Alluvial Fan. Xinzhou Basin, Shanxi, China. Environ Manag. 2009;44(2):243-55.

6. Trabelsi R, Kacem A, Zouari K, Rozanski K. Quantifying regional groundwater flow between Continental Intercalaire and Djeffara aquifers in southern Tunisia using isotope methods. Environ Geol. 2009;58(1):171-83.

7. Werner AD, Ward JD, Morgan LK, Simmons CT, Robinson NI, Teubner MD. Vulnerability indicators of sea water intrusion. Ground Water. 2012;50(1):48-58.

8. Li P, Qian H, Wu J, Zhang Y, Zhang H. Major ion chemistry of shallow groundwater in the Dongsheng coalfield, Ordos Basin, China. Mine Water Environ. 2013;32(3):195-206.

9. Marghade D, Malpe DB, Zade AB. Major ion chemistry of shallow groundwater of a fast growing city of Central India. Environ Monit Assess. 2012;184(4):2405-18.

10. Yadav KK, Gupta N, Kumar V, Sharma S, Arya S. Water quality assessment of Pahuj River using water quality index at Unnao Balaji, M.P., India. International Journal of Sciences. Basic and Applied Research. 2014; 19 (1):241-250.

11. Baumhardt RL, Wendt CW, Moore J. Infiltration in response to water quality, tillage and gypsum. Soil Science Society of America Journal. 1992; 56(1): 261-266.

12. DPHE-BGS. Groundwater studies for arsenic contamination in Bangladesh. Department of Public Health Engineering and British Geological Survey; 2000. p.11-49.

13. UNDP (United Nations Development Program). Groundwater Survey, The Hydrological Condition of Bangladesh. UNDP Technical Report DP/UN/BGD-74009/1; 1982. p. 113.

14. APHA (American Public Health Association). Standard Methods for the Examination of Water and Wastewater, 21th ed. American Public Health Association, Washington, DC;2005.

15. Gulgundi MS, Shetty A. Groundwater quality assessment of urban Bengaluru using multivariate statistical techniques. Applied Water Science. 2018; 8(1):1-15.

16. Nikanorov AM, Brazhnikova LV. Types and Properties of Water II: Water Chemical Composition of Rivers, Lakes and Wetlands; 2012. p. 42-76.

17. Pradhan B, Pirasteh S. Hydro-chemical analysis of the ground water of the basaltic catchments: upper Bhatsai region, Maharastra. The Open Hydrology Journal. 2011; 5: 51-57.

18. Herojeet RK, Rishi MS, Sidhu N. Hydrochemical Characterization, Classification and Evaluation of Groundwater Regime in Sirsa Watershed, Nalagarh Valley, Himachal Pradesh, India. Civil and Environmental Research. 2013; 3(7):47-57.

19. Yousaf M, Ali OM, Rhoades JD. Dispersion of clay from some salt-affected, and land soil aggregates. Soil Science Society of America Journal. 1987; 51(4):920-924. 
20. Krishna Kumar S, Rammohan V, RajkumarSahayam J, Jeevanandam M. Assessment of groundwater quality and hydrogeochemistry of Manimuktha River basin, Tamil Nadu, India. Environmental Monitoring and Assessment. 2009; 159(1-4):341-351.

21. Datta PS, Tyagi SK. Major ion chemistry of groundwater in Delhi area: chemical weathering processes and groundwater flow regime. Journal of the Geological Society of India. 1996; 47(2):179-188.

22. Lakshmanan E, Kannan R, Kumar MS. Major ion chemistry and identification of hydrogeochemical processes of ground water in a part of Kancheepuram district, Tamil Nadu, India. Environmental Geosciences. 2003; 10(4):157-166.

23. Kim K. Long-term disturbance of groundwater chemistry following well installation. Ground Water. 2003; 41(6):780-789.

24. Li P, Wu J, Qian H. Hydrogeochemical characterization of groundwater in and around a wastewater irrigated forest in the southeastern edge of the Tengger Desert, Northwest China. Expo Health. 2016b; 8(3): 331-348. doi:10.1007/ s12403-016-0193-y

25. Jalali M. Hydrochemical identification of groundwater resources and their changes under the impacts of human activity in the Chah Basin in Western Iran. Environmental Monitoring and Assessment. 2007; 130 (1-3):347-364.

26. Hounslow A. Water Quality Data Analysis and Interpretation. Lewis Publishers, Boca Raton, USA; 1995. p. $86-87$.

27. Wayland KG, Long DT, Hyndman DW, Pijanowski BC, Woodhams SM, Haack ShK. Identifying relationships between base flow geochemistry and land use with synoptic sampling and R-Mode factor analysis. Journal of Environmental Quality. 2003; 32(1):180-190.

28. Sonkamble S, Sahya A, Mondal NC, Harikumar P. Appraisal and evolution of hydrochemical processes from proximity basalt and granite areas of Deccan Volcanic Province (DVP) in India. Journal of Hydrology. 2012; 438-439:181-193.

29. Cartwright I, Weaver T, Petrides B. Controls on $87 \mathrm{Sr} / 86 \mathrm{Sr}$ ratios of groundwater in silicate-dominated aquifers: SE Murray Basin, Australia. Chemical Geology. 2007; 246(1-2):107-123.

30. Fisher RS, Mulican WF. Hydrochemical evolution of sodium sulphate and sodium-chloride groundwater beneath the Northern Chihuahua desert, Trans-Pecos, Texas, USA. Hydrogeology Journal. 1997; 5(2):4-16.

31. Yidana SM, Yidana A. Assessing water quality using water quality index and multivariate analysis. Environmental Earth Sciences. 2010; 59(7):1461-1473.
32. Schoeller H. Geochemistry of groundwater. In: Groundwater studies-an international guide for research and practice. UNESCO, Paris; 1977. Ch. 15, pp.1-18.

33. Wu H, Chen J, Qian H, Zhang X. Chemical characteristics and quality assessment of groundwater of exploited aquifers in Beijiao Water Source of Yinchuan, China: A case study for drinking, irrigation, and industrial purposes. Journal of Chemistry. 2015; Article ID 726340, http://dx.doi. org/10.1155/2015/726340

34. Gibbs RJ. Mechanism controlling world's water chemistry. Science. 1970; 170(3962):1088-1090.

35. Karanth KR. Groundwater Assessment Development and Management. TATA McGraw-Hill Publishing Company Limited, New Delhi; 1994. pp. 217-273.

36. Piper AM. A graphic procedure in the geochemical interpretation of water-analyses. Transactions of the American Geophysical Union. 1944; 25(6):914-928. doi:10.1029/TR025i006p00914

37. Liu CW, Lin KH, Kuo YM. Application of factor analysis in the assessment of groundwater quality in a blackfoot disease area in Taiwan. Science of the Total Environment. 2003; 313:77-89.

38. Ayers RS, Westcot DW. Water Quality for Agriculture, FAO Irrigationand Drainage Paper.1985; 29:1-144.

39. Wilcox LV. Classification and use of irrigation water, USDA, Washington (Circular 969). 1955.

40. Richards LA (Ed.). Diagnosis and Improvement of Saline and Alkali Soils. Agricultural Hand Book 60, USDA and IBM. Publishing Co. Ltd. New Delhi, India; 1968. p. 98-99.

41. Freeze AR, Cherry JA. Groundwater. Prentice Hall, Inc. Englewood Cliffs, New Jersey 07632; 1979. p. 604.

42. Duncan RR, Carrow RN, Huck M. Understanding water quality and guidelines to management (an overview of challenges for water usage on golf courses for the 21 century, USGA Green Section Record; 2000. p.14-24.

43. WHO. Guidelines for drinking water quality. World Health Organization, Geneva; 2011. p. 541.

44. Sawyer CN, McCarty PL. Chemistry of Sanitary Engineers', 2nd ed., McGraw Hill, New York; 1967. p. 518.

45. Eaton FM. Significance of carbonate in irrigation waters. Soil Science. 1950; 67:12-133.

46. Kelly WP. Permissible composition and concentration of irrigated waters. Proceedings of the American Society of Civil Engineers. 1940; 66:607-613. 